\title{
EFEKTIVITAS PEMBELAJARAN BASIS ONLINE DI IAIN TULUNGAGUNG DENGAN ADANYA KEBIJAKAN PHYSICAL DISTANCING ERA PANDEMI COVID 19
}

\author{
Alifarose Syahda Zahra $^{1}$, Sherina Wijayanti ${ }^{2}$ \\ Universitas Kahuripan Kediri, IAIN Tulungagung, Indonesia ${ }^{1,2}$ \\ alifarose@kahuripan.ac.id ${ }^{1}$, Shersherina21@gmail.com ${ }^{2}$
}

\begin{abstract}
This research focused on the effectiveness of online based-learning applications that are applied due to physical distancing policies. Physical distancing was applied by the Indonesian government as a preventive for the transmission of the COVID 19 virus, but it was not very successful because positive numbers continue to grow. COVID pandemic 19 changed various people's lifestyles in all fields including the education sector. The irony of the impact occurring in the education sector related to student finances which dropped dramatically without any income. There was news of a pseudo UKT 10\% discount policy. This has decreased the spirit of students in learning because online learning uses a large quota. Various learning applications are gaining in popularity among students ranging from paid to not. Experiments on each application showed the advantages and disadvantages of each. Hadith Sciences students as a sample in this research responded that the application of Whatsapp was more effective. This research used purposive sampling by using a questionnaire as data collection material, and literature study as an approach model. The results of the research were: 1) Pillar of pandemic era bourgeois public unrest, 2) Discourse on UKT reduction policy, 3) Diffusion of online applications.
\end{abstract}

Keywords: online application, students, virus

\begin{abstract}
ABSTRAK
Kajian penelitian ini berfokus pada efektivitas aplikasi pembelajaran basis online yang diterapkan akibat kebijakan physical distancing. Physical distancing (jaga jarak) diterapkan pemerintah Indonesia sebagai preventif penularan virus covid 19, namun tidak begitu berhasil sebab angka positif terus bertambah. Pandemi covid 19 mengubah berbagai gaya hidup masyarakat dalam segala bidang termasuk sektor pendidikan. Ironi dampak yang terjadi dalam sektor pendidikan berkaitan finansial mahasiswa yang menurun drastis tanpa ada pemasukan. Sempat ada kabar kebijakan diskon $10 \%$ UKT yang semu. Hal ini menjadi penurunan spirit mahasiswa dalam belajar sebab pembelajaran basis online mamakai kuota yang besar. Berbagai aplikasi belajar mulai populer dikalangan pelajar mulai dari yang berbayar hingga tidak. Percobaan pada tiap aplikasi menunjukkan kekurangan dan kelebihan masing-masing. Bagi mahasiswa IAIN Tulungagung dengan pengambilan sempel pada mahasiswa Ilmu Hadis menunjukkan bahwa aplikasi whatsapp lebih efektif. Penelitian ini menggunakan purposive sampling dengan menggunakan angket sebagai bahan pengumpulan data, dan studi kepustakaan sebagai model pendekatan. Penelitian ini menghasilkan: 1) Pilar keresahan masyarakat borjuis era pandemi, 2) Diskursus kebijakan penurunan UKT, 3) Difusi aplikasi daring.
\end{abstract}

Kata Kunci: aplikasi daring, mahasiswa, virus

\section{PENDAHULUAN}

Tragedi pandemi covid 19 diakhir tahun 2019 merupakan boomerang bagi seluruh negara dunia yang belum tertuntaskan.
Bermula dari kota wuhan virus terus menyebar dengan penularan udara, dan kontak fisik. (Lalo, 2018) Penyebaran yang begitu cepat dengan resiko kematian tinggi bagi lansia, 
orang dengan penyakit penyerta, balita, dan tenaga medis berimbas pemberlakukan sistem lockdown. Catatan jumlah kasus terakhir dunia pada 8 Mei 2020 terdapat 3.917.532 positif, 270.720 kematian, dan 1.344.120 sembuh.

Pemberlakuan sistem lockdown pertama kali akibat covid 19 pada tanggal 23 Januari 2020, dilakukan di negara Cina dengan pencatatan 3.261 kematian. (Susilo et al. 2020) Sistem lockdown tidak hanya membatasi aktivitas masyarakat, melainkan menurunkan perekonomian beberapa negara dunia baik negara maju maupun negara berkembang. Hal ini menarik persaingan antar negara dalam menemukan vaksin penawar virus covid 19 .

Virus covid 19 menyerang sistem imun tubuh dengan menghambat sistem pernafasan. Ciri khas yang paling rendah diantaranya demam disertai batuk, dan flu yang semakin hari membuat tubuh lemah hingga sulit dalam pernapasan, dan puncaknya kematian (Yuliana, 2020). Penggunaan masker, handsinitizer, dan penyempro-tan disenfektan solusi tepat upaya prefentif penularan.

Selain bidang kesehatan yang menyerang imunitas tubuh, virus corona juga menyerang perekonomian rakyat yang berdampak pada adminitrasi pendidikan. Adminitrasi dalam pendidikan tidak ada perubahan meskipun sistem pembelajaran sudah berubah tidak lagi menggunakan fasilitas kampus, yakni berbasis online.

Pendidikan sebagai salah satu senter pergerakan bangsa bermasalah secara finansial dan psikis anak di masa Pandemi covid 19. (Purmadi, Hadi, dan Najwa, 2018) Secara finansial permasalahan terletak pada pembayaran UKT yang tidak ada kebijakan keringanan. Sedangkan psikis anak mulai terganggu sebab pembelajaran yang tidak ada libur secara terus menerus dosen memberikan tugas secara bersamaan melalui basis online dengan penggunaan teknologi laptop atau komputer. Permasalahannya adalah masih ada mahasiswa yang tidak memiliki laptop sehingga saat pemberlakuan physical distancing sangat meresahkan pikiran anak untuk mencari pinjaman laptop atau harus pergi ke warnet secara terus menerus agar dapat mengikuti pembelajaran yang berbasis aplikasi online.

Tidak dipungkiri dimasa pandemi ragam alternatif penawaran aplikasi pembelajaran online, kian laku dikalangan kaum intelek yang mengharuskan penguasaan teknologi secara seimbang. (Mustofa, Chodzirin, dan Sayekti, 2019) Tidak hanya mahasiswa, namun juga dosen yang harus lebih cakap dalam penguasaan teknologi secara maksimal dengan metode pembaharuan yang layak.

Hasil survey kuisioner di IAIN Tulungagung yang mengambil sempel pengisian dari seluruh mahasiswa jurusan Ilmu Hadis terdapat $80 \%$ responden pada 5 Mei 2020 menunjukkan meskipun telah tersedia berbagai fasilitas pembelajaran basis online tetap tidak efektif dalam sistem pembelajaran. Kebanyakan mahasiswa milenial lebih menyukai perkuliahan offline dari pada online.

Isu mencengangkan penurunan UKT yang tidak terealisasikan menjadi suplemen tambahan untuk kemalasan mahasiswa milenial. Terutama bagi mahasiswa dari kalangan kelas menengah yang tidak mendapat bantuan beasiswa. Ketimpangan pengeluaran mahasiswa secara pribadi dengan tidak terpenuhinya hak fasilitas kampus, dimasa pandemi covid 19 termasuk faktor yang memperkeruh keadaan sistem pendidikan.

Pembelajaran berbasis online mmiliki kelemahan diantaranya ketergantungan terhadap sambungan internet, khsususnya jika menggunakan handphone sebagai alat operasionalnya kadang kala sambungan internet tidak stabil dan tentunya membutuhkan kuota yang lebih (Haryanto, 2018).

Selama masa pandemi pembelajaran dilakukan daring secara penuh pada semua mata kuliah, termasuk mata kuliah Bahasa Indonesia yang ditetapkan dilakukan secara online. Hal ini memicu persaingan popularitas aplikasi daring yang menawarkan metodemetode pembelajaran yang efektif. Bahkan akun-akun sosial beralih fungsi sebagai alat pembelajaran daring, seperti youtube, instagram, dan whatsapp.

Selama penetapan aturan kuliah berbasis online, mata kuliah Bahasa Indonesia 
dilakukan melalui sosial media whatsapp. Aplikasi ini tidak hanya dapat berinteraksi chating tetapi juga dapat menampung dokumen dalam bentuk PowerPoint (PPt). selama ini tenaga pengajar memberikan PPt, kemudian memberikan penjelasan dari PPt yang diberikan. Tidak hanya itu saja, juga terdapat diskusi terbuka yang dilakukan dalam bentuk tulisan maupun pesan suara dalam whatsapp.

Dengan penerapan aturan tersebut memang secara nayata mahasiswa akan kehilangan interaksi langsung dengan para tenaga pengajar khususnya interaksi secara verbal, namun sisi baik dari penerapan perkuliahan menggunakan media whatsapp ini memberikan keuntungan dalam hal yang lain yaitu para mahasiswa akan membiasakan diri untuk menyusun kalimat sesuai dengan kaidah sistematika penulisan Bahasa Indonesia untuk berinteraksi dalam perkuliahan baik pada saat memberikan pertanyaan ataupun memberikan tanggapan dari setiap situasi diskusi yang ada.

Berdasarkan data yang telah dipaparkan penulis membuat penelitian ini dengan tujuan memberikan penawaran gagasan seputar alternatif pendidikan basis online yang efektif digunakan masa pandemi covid 19, serta pengaruh physical distancing dikalangan mahasiswa Indonesia.

\section{METODOLOGI PENELITIAN}

\begin{tabular}{|c|c|}
\hline Adapun & metode \\
\hline $\begin{array}{l}\text { nenggunakan } \\
\text { nenggunakan }\end{array}$ & $\begin{array}{cc}\text { purposive } & \text { sampling } \\
\text { angket } & \text { sebagai }\end{array}$ \\
\hline
\end{tabular}
penumpulan data, dan studi kepustakaan sebagai model pendekatan. Urgensi ditarik mengenai pengaruh kebijakan physical distancing dimasyarakat era pandemi. Ruang lingkup penelitian ini dampak pandemi covid 19 bidang pendidikan, dan ragam aplikasi alternatif daring. Pemerintah sudah seharusnya memberikan kebijakan yang terbaik untuk masyarakat dengan totalitas, agar kekhawatiran masyarakat tidak menjadi boomerang untuk kesejahteraan negara.

HASIL DAN PEMBAHASAN Orientasi Bias Physical Distancing
Indonesia sebagai salah satu negara yang terkena dampak covid 19 memiliki cara yang berbeda dalam upaya preventif pandemi. Tidak seperti negara lain yang memberlakukan sistem lockdown secara berkala, Indonesia memilih sistem jaga jarak atau physical distancing. UU no.6 tahun 2018 memaparkan bahwa kebijakan lockdown sama dengan karantina wilayah yang membatasi gerak warga negara Indonesia. (Presiden, 2018) Negara ini memilih untuk tidak melakukan pembatasan gerak secara penuh dengan bukti penetapan keputusan presiden (Keppres) no.9 tahun 2020 (Presiden, 2020).

Pemberlakuan sistem jaga jarak melalui buka tutup jalan penghubung antar kota, adapun beberapa daerah yang redzone diadakan PSBB (Pembatasan Sosial Berskala Besar) sebagai pencegahan akses mudik tahun ini. Presiden Jokowi menegaskan bahwa Indonesia tidak akan melakukan lockdown seperti negara-negara lain. Upaya ini baik namun tidak memberikan hasil alternatif lain yang efisien terlihat dari angka positif yang terus bertambah.

Sejarah dunia mencatat pemberlakuan sistem lockdown lebih efisien menekan arus pertambahan korban covid seperti yang telah dilakukan negara Cina, India, Malaysia, Porlandia, El savor, Irlandia, Spanyol, Denmark, Filipina, Lebanon, Prancis, Belgia, Selandia baru, Amerika Serikat, Rwanda, Inggris, Afrika selatan, dan Thailand (Sanur, 2020) Penemuan vaksin sudah mulai ada di Cina, dan Amerika Serikat jika sudah mencukupi jumlah warga dunia akan didistribusikan bulan juni. Walaupun demikian seluruh negara dunia tetap dihimbau oleh WHO memakai masker baik penderita maupun orang yang sehat.

Indonesia memeroleh berbagai kritik masyarakat terutama bagi keluarga yang ekonomi rendah, sebab kehidupan mereka tertompang dari hasil pekerjaan informal yang harus mengikuti aturan pembatasan sosial demi pencegahan penularan covid 19, seperti pedagang kecil kaki lima, sopir, grab, dsb. Isi maklumat amanat penderitaan rakyat "akibat corona rakyat makin susah, rakyat makin sulit isi perut keluarga" menunjukkan betapa 
khawatirnya warga negara Indonesia masa pandemi ini. Adapun bantuan-bantuan dari pemerintah belum semuanya diterima rakyat serentak. Mirisnya hanya warga asli daerah yang mendapat bantuan sedangkan bagi para pelancong yang tidak bisa mudik hanya menggantungkan nasib.

Ironi kebijakan pembebasan narapidana Indonesia yang justru menambah kekhawatiran warga Indonesia sebab angka kejahatan begal, dan rampok kembali menerobos keamanan. Banyak pula warga yang telah mencuri kesempatan mudik sebelum bulan ramadhan tiba tanpa ketegasan aparat pemerintah. Physical distancing seakan hanya nama yang tidak memberikan solusi tepat.

Fakta yang terjadi di lapangan dari kuisioner yang telah diisi mahasiswa jurusan Ilmu Hadis, menunjukkan warga negara masih belum merasa tenang atas segala kebijakan pemerintah dalam penangan covid 19. Hal ini terlihat jelas dari finansial tiap-tiap keluarga mahasiswa yang menurun drastis bahkan tidak ada pemasukan. Pemberlakuan PHK serta penutupan beberapa pabrik yang teridentifikasi covid 19 menambah angka pengangguran yang cukup besar. Bahkan beberapa tenaga medis ikut terjerumus dalam angka kematian covid 19.

\section{Krisis Pendidikan Milenial Era Covid 19}

Pada sektor pendidikan kejaman keras berlaku dalam lingkup kampus yang tetap melaksanakan UKT secara penuh. Adapun sempat beredar kabar diskon $10 \%$ UKT melalui surat edaran nomor B752/DJ.I/HM.00/04/2020 telah dicabut dengan surat edaran nomor B802/DJ.I/PP.00.9/04/2020 yang ditanda tangani Plt. Direktur Jendral Kamaruddin Amin. Kekecewaan mahasiswa Indonesia seakan menjadi pertanda kesensaraan rakyat masa yang akan datang. Sebagian calon mahasiswa sudah banyak yang berencana tidak jadi kuliah sebab permasalahan UKT.

Mahasiswa Indonesia merasa sangat keberatan dengan masa pandemi yang lebih banyak menggunakan akses kuota internet dengan mengandalkan signal yang kuat. Jaringan yang terputus adalah hambatan yang sering terjadi ketika pembelajaran berlangsung. Sedangkan tuntutan kehadiran dalam kelas online menjadi penilaian tinggi keaktifan kelas (Niki, n.d., 2010).

Skenario agenda kegiatan kampus harus mengalami banyak pembatalan bahkan beralih fungsi daring (Mustofa, Chodzirin, dan Sayekti, 2019) Penguasaan teknologi yang urgen dibutuhkan tidak hanya untuk kalangan mahasiswa namun juga dosen sebagai senter pengajar. Pengajar era masa kini harus lebih terbuka dengan mengikuti pemikiranpemikiran baru. Mereka harus mendidik peserta didik sesuai zamannya dengan batasan tidak melanggar norma yang berlaku.

Pendidikan mengolah pikiran peserta didik dengan arahan yang diberikan tutor baik formal maupun informal (Barni 2019). Pada jenjang ini yang perlu diperhatikan adalah pendidikan informal sebab karakter anak mengikuti tren pada zamannya (Lalo, 2018). Contohnya karakter anak zaman 0.1 akan berbeda dengan anak zaman 4.0 yang mana anak zaman 0.1 lebih bersifat independen. Jika tidak dilakukan kontrol maka anak akan terlalu bebas masuk ke dalam penguasaan teknologi yang salah pada jenjang usianya.

Telah dilansir beberapa penelitian mengenai perubahan karakter anak sesuai perkembangan zaman. Pertama, generasi X (1930-1980) lahir awal dari perkembangan teknologi informasi, seperti komputer, video games, TV kabel, dan internet. Generasi ini mampu beradaptasi dengan perubahan sehingga dikatakan generasi yang tanggung karakter. Karakteristik generasi ini memiliki banyak akal, indepen, lebih menyukai sesuatu non formal, dan butuh kenyamanan emosional.

Kedua, generasi Y (1980-1995) dikenal dengan generasi milenial yang lahir era internet booming, sehingga banyak menggunakan teknologi komunikasi instan, seperti SMS, email, dll. Generasi ini lebih terbuka dalam pandangan politik dan ekonomi. Mereka terlihat reaktif atas perubahan lingkungan disekelilingnya. Karakteristiknya menyukai peraturan yang tidak berbelit-belit, menyukai keterbukaan, dan transparansi.

Ketiga, generasi Z (1995-sekarang) biasa disebut dengan generasi internet atau 
igeneration. Generasi ini lebih banyak berhubungan sosial lewat dunia maya, dan sejak dini telah dikenalkan dengan teknologi sehingga disebut generasi kreatif. Karakteristiknya lebih menyukai kegiatan sosial dibandingkan generasi sebelumnya, multi tasking, ahli dalam mengoprasikan teknologi, mudah terpengaruh lingkungan mengenai produk bermerek, pintar, dan mudah menangkap informasi secara cepat.

Ketiga generasi ini memiliki karakter yang berbeda terutama generasi $\mathrm{Y}$ dan $\mathrm{Z}$ sebagai titik fokus problematik masa kini. Meskipun sudah terbiasa dengan teknologi informasi, generasi ini masih banyak yang kurang ahli dalam filtrasi informasi yang beredar. Tidak jarang generasi ini mengkonsumsi berita hoax secara cuma-cuma yang menjadi bibir dimasyarakat. Peran pendidikan menjadi benteng penyelamat generasi ini agar tidak mudah terpengaruh polemik dunia maya.

Sebelum terjadi pandemi pendidikan berjalan normal dengan tidak hanya mengandalkan penguasaan teknologi. Pergerakan mahasiswa terealisasikan dengan mudah tanpa ada hambatan jaga jarak. Begitupula pula finansial tiap-tiap keluarga mahasiswa diseluruh kalangan profesi. Mirisnya pandemi memanjakan seluruh peserta didik dengan berbagai aplikasi yang kurang mendukung pembelajaran seperti games, facebook, twitter, tiktok dan lainnya yang lebih menekankan eksistensi sosial (Kuntaro, 2017). Bahkan banyak juga terjadi pengumpulan tugas yang tidak sesuai deadline atau kurang maksimal dalam pengerjaan sebab kemalasan yang muncul akibat pandemi.

\section{Efisiensi Metode Pembelajaran Aplikasi Daring}

Keadaan pandemi merubah segala sistem aktivitas masyarakat mulai dari menjaga jarak satu meter sampai beralih Online Learning Model (OML) (Adhe, 2018). Hal ini sangat efisien diterapkan sebab kasus pandemi yang terus bertambah. Awal terjadinya pandemi sempat merisaukan peserta didik, apalagi mahasiswa yang dituntut lebih banyak aksi dimasyarakat.
Indonesia melansir pemberlakuan aktivitas belajar di rumah atau bekerja di rumah sampai keadaan pulih kembali. Berbagai aplikasi ditawarkan untuk memudahkan peserta didik menyerap ilmu yang diberikan oleh turor. Penggunaan sistem voice note, recorder, massage, vidcall, dan pengiriman file tugas menjadi langkah pendidikan basis online. Kehadiran peserta didik ditinjau dari banyaknya penggunaan sistem tersebut.

Berdasarkan survei kuisioner 81,5\% Mahasiswa IAIN Tulungagung memiliki laptop atau komputer yang mana selain itu mahasiswa hanya mengandalkan HP. Aplikasi pembela-jaran yang sering diakses antara lain; whatsapp, zoom, google classroom, discord, dan youtube. Semua aplikasi tersebut memiliki keunggulan, dan kekurangan yang berbedabeda namun $60 \%$ mahasiswa memilih whatsapp sebagai alternatif efisien pembelajaran.

Aplikasi whatsapp memungkin-kan mahasiswa dalam mempresentasi-kan makalah dengan baik melalui voice note. Metode pembelajaran yang ditawarkan dari aplikasi dengan babak awal berupa teks atau voice note yaitu (1) saling sapa antara dosen dengan mahasiswa, (2) dosen memberikan gambaran umum mata kuliah yang akan dipelajari, (3) peraturan dan penjelasan capaian pembelajaran.

Babak kedua masuk dalam penyajian materi yang dikemukakan mahasiswa, yaitu (1) Mengirim data uraian bahan ajar (studies notes, ppt, makalah, video, links, dll), (2) Mengirimkan voice note sebagai penjelasan uraian bahan ajar yang telah disediakan, (3) memulai diskusi yang lebih efektif diatur oleh moderator.

Babak ketiga penutup, yaitu (1) pemakalah menutup diskusi dengan memberikan kesimpulan, (2) dosen menanggapi berbagai pertanyaan, dan jawaban yang telah dibahas oleh mahasiswa, (3) refleksi saran dari dosen untuk mahasiswa berkaitan dengan pembahasan materi yang relevan dimasyarakat.

Kelebihan menggunakan metode pembelajaran melalui aplikasi whatsapp yang 
urgen adalah dosen bisa aktif dalam menjelaskan materi dibandingkan aplikasi lain yang kemungkinan besar aktif hanya mahasiswa dengan pengumpulan tugas. Adapun kelebihan lainnya lebih hemat kuota dari pada aplikasi lainnya.

Aplikasi lain yang ramah akan kuota, dan signal adalah discord. $15 \%$ mahasiswa menyukai aplikasi ini. Discord sejenis aplikasi whatsapp hanya saja lebih mengutamakan perbincangan via suara, dan komentar pada tampilan umum. Aplikasi ini lebih mengutama-kan topik pembicaraan tidak tatap muka yang efektif untuk diskusi.

Metode yang ditawarkan aplikasi discord dengan melakukan panggilan suara via grup, dimana tiap personal dapat mengatur mute yang terdapat saat telpon seksama. Hal ini bisa dimanfaatkan ketika pemakalah menyampaikan materi yang disimak peserta lain tanpa ada gangguan suara dari penyimak. Kemudian penyimak dapat memberikan tanggapan melalui komentar ditampilan umum saat panggilan berlangsung. Biarpun kondisi signal E tetap bisa menyimak dalam aplikasi ini.

Perkuliahan daring memiliki kekurangan dalam hal referensi serta penggunaan gadged yang merusak mata. Walaupun tersedia perpustaan digital tetap saja tidak bisa memenuhi kebutuhan referensi peserta didik. Dosen atau tutor sudah seharusnya memiliki cara-cara efektif untuk menghidupkan suasana kelas agar mahasiswa tidak jenuh bahkan tertidur saat pembelajaran berlangsung.

Jika aplikasi sejenis whatsapp, dan discord sudah terbukti efektif, berbeda halnya dengan aplikasi google classroom. Aplikasi ini lebih mengolah peserta didik aktif dibandingkan tutor yang hanya membagikan materi, dan tugas tanpa penjelasan suara. Sedangkan kebanyakan peserta didik akan memahami materi melalui penjelasan secara langsung via suara.

\section{SIMPULAN}

Sejak pandemi covid 19 berbagai mata rantai aktivitas masyarakat dibatasi hingga menelan pekerjaan masyarakat. Krisis yang terjadi tidak menyulutkan langkah pemerintah memberlakukan physical distancing. Sebagian masyarakat menilai bahwa langkah pemerintah tidaklah tepat. Hal ini terbukti dengan angka penularan covid 19 yang terus mengalami pertambahan. Meskipun tercatat sudah ada yang sembuh, namun tidak sebesar pertambahan penularan.

Imbas dari pandemi ini merasuk dunia akademik secara tiba-tiba memberhentikan kegiatan offline. Mahasiswa yang pergerakannya terjun langsung masyarakat terpaksa berhenti mengikuti aturan kampus. Sempat beredar kabar terjadi penurunan UKT $10 \%$ melalui surat edaran nomor B752/DJ.I/HM.00/04/2020, ternyata ha-nya sekedar kabar dengan pernyataan melalui surat edaran nomor B-802/DJ.I/PP.00.9/04/2020.

Latar belakang mahasiswa yang saat ini sedang mengalami kesusahan ekonomi sebab banyak terjadi PHK, bahkan ada penutupan pasar sebab sepi pembeli tidak menjadi pertimbangan pemerintah untuk kebijakan penurunan UKT.

Sistem pendidikan offline beralih online yang menerapkan pembelajaran melalui berbagai aplikasi internet. Ragam aplikasi yang ditawarkan memiliki keunggulan dan kekurangan yang berbeda-beda. Walau demikian ada aplikasi yang efisien menghemat kuota, seperti whatsapp, dan discord. Tentunya dimasa pandemi ini kendala terbesar adalah pengeluaran yang tidak seimbang dengan pemasukan. Pada dunia akademik seharusnya ada kebijakan penurunan UKT, sebab mahasiswa tidak sepenunya memakai fasilitas kampus bahkan banyak pengeluaran untuk membeli kuota internet.

\section{REFERENSI}

Adhe, Kartika Rinakit. 2018. "Model Pembelajaran Daring Matakuliah Kajian PAUD Di Jurusan PG PAUD Fakultas Ilmu Pendidikan Universitas Negeri Surabaya Online Learning Model PAUD Study in PG PAUD Education Faculty of Surabaya State University".

Barni, Mahyuddin. 2019. "Tantangan Pendidik Di Era MillenniaL Mahyuddin Barni." Islamic Studies 3 (1). 
Haryanto, Sigit. 2018. "Kelebihan Dan

Kekurangan E-Learning Berbasis

Schoology." Prosiding Seminar Nasional Geotik, no. 2016.

Kuntaro, Eko. 2017. "Keefektifan Model Pembelajaran Daring Dalam Perkuliahan Bahasa Indonesia Di Perguruan Tinggi." Journal Indonesian Language Education and Literature 3 (1).

Lalo, Kalfaris. 2018. "Menciptakan Generasi Milenial Berkarakter Dengan Pendidikan Karakter Guna Menyongsong Era Globalisasi." Ilmu Kepolisian.

Mustofa, Mokhamad Iklil, Muhammad Chodzirin, dan Lina Sayekti. 2019. "Formulasi Model Perkuliahan Daring Sebagai Upaya Menekan Disparitas Kualitas Perguruan Tinggi." Walisongo Journal of Information Technology 1 (2).

Niki, Raga Tantri. n.d. 2010 "Kehadiran Sosial Dalam Pembelaja-Ran Daring." Pendidikan Terbuka Dan Jarak Jauh 3.

Presiden. 2018. "Undang-Undang Republik Indonesia Nomor 6 Tahun 2018."

- 2020. "Keppres Nomor 9 Tahun 2020.Pdf."

Purmadi, Ary, M.Samsul Hadi, dan Lu'luin Najwa. 2018. "Pengembangan Kelas Daring Dengan Penerapan Hybrid Learning Menggunakan Chamilo Pada Matakuliah Pendidikan Kewarganegaraan." Edcomtech.

Sanur, Debora. 2020. "Wacana Kebijakan Lockdown Dalam Menghadapi Covid-19 Di Indonesia" 12 (6).

Susilo, Adityo, C Martin Rumende, Ceva W Pitoyo, Widayat Djoko Santoso, Mira Yulianti, Robert Sinto, Gurmeet Singh, et al. 2020. "Coronavirus Disease 2019: Tinjauan Literatur Terkini Coronavirus Disease 2019: Review of Current Literatures." Pendidikan Terbuka Dan Jarak Jauh 7 (1).

Yuliana. 2020. "Wellness and Healthy Magazine." Wellness and Healthy Magazine 2 (February). 